\title{
PENGARUH ACCEPTANCE AND COMMITMENT THERAPY (ACT) TERHADAP PENURUNAN KECEMASAN PADA PEREMPUAN KORBAN KEKERASAN SEKSUAL
}

\author{
Anindita Nova Ardhani ${ }^{1}$, Sri Kandariyah Nawangsih ${ }^{2}$ \\ 1,2Fakultas Psikologi, Universitas Semarang \\ anindita@usm.ac.id
}

\begin{abstract}
The experiences that occur in life are not all pleasant experiences. Experiencing sexual violence for women is a negative experience that is very painful and adversely affects psychological conditions. Sexuality is a complex and sensitive matter that not only involves biological aspects but also psychological and social aspects so that victims of sexual violence are very likely to experience clinical symptoms. Clinical symptoms that may be experienced are anxiety. Handling and healing anxiety that is a sign of psychological trauma due to sexual violence must be considered so that the impact of sexual violence on newspapers does not damage the quality of life of ACT victims helping to continue to find happiness in the midst of unpleasant situations due to negative experiences experienced by receiving it. Based on this, the study aims to see a decrease in anxiety in victims of violence by using the ACT method. The subjects in this study were two women victims of sexual violence. The method used in this study is an experiment by giving ACT to women victims of sexual violence then seeing the decrease in anxiety that it causes. ACT is proven to be able to increase psychological flexibility and increase acceptance. There is a decrease in anxiety which is the impact of ACT. This research is expected to be a useful study for handling similar cases.
\end{abstract}

Keywords: sexual violence, anxiety, ACT

\begin{abstract}
Abstrak. Pengalaman-pengalaman yang terjadi dalam kehidupan tidak semuanya merupakan pengalaman yang menyenangkan. Mengalami kekerasan seksual bagi perempuan merupakan pengalaman negatif yang sangat menyakitkan dan berdampak buruk pada kondisi psikologis. Seksualitas merupakan sesuatu yang kompleks dan sensitif yang tidak hanya menyangkut aspek biologis saja namun juga aspek psikologis dan juga sosial sehingga korban kekerasan seksual sangat mungkin mengalami gejala klinis. Gejala klinis yang mungkin dialami adalah kecemasan. Penanganan dan penyembuhan kecemasan yang menjadi tanda terjadinya trauma psikis akibat kekerasan seksual haruslah mendapat perhatian agar dampak kekerasan seksual pada koran tidak merusak kualitas hidup korban ACT membantu untuk tetap bisa merasakan kebahagiaan walaupun mengalami situasi yang tidak menyenangkan karena pengalaman negatif yang dialami dengan cara menerimanya. Berdasarkan hal tersebut, penelitian bertujuan untuk melihat penurunan kecemasan pada korban kekerasan dengan menggunakan metode ACT. Subjek dalam penelitian ini adalah dua orang wanita korban kekerasan seksual. Metode yang digunakan dalam penelitian ini adalah eksperimen dengan memberikan memberikan ACT pada wanita korban kekrasan seksual kemudian melihat penurunan kecemasan yang ditimbulkannya. ACT terbukti mampu meningkatkan fleksibilitas psikologis dan meningkatkan penerimaan. Terdapat penurunan kecemasan yang merupakan dampak dari pemberian ACT. Penelitian ini diharap bisa menjadi kajian yang berguna bagi penanganan kasus serupa.
\end{abstract}

Kata kunci : kekerasan seksual, kecemasan, ACT 


\section{Pendahuluan}

Kasus kekerasan seksual terus mengalami peningkatan dari waktu ke waktu. Kita bisa melihat dan membaca di media massa bahwa hampir setiap hari ada berita mengenai kasus-kasus yang berhubungan dengan kekerasan seksual. Korban kekerasan seksual mayoritas adalah perempuan. Perempuan memiliki kerentanan menjadi korban kejahatan (victim of crime) terutama di bidang kesusilaan karena di antara dua jenis gender yang ada perempuan adalah gender yang dianggap lebih lemah daripada laki-laki. Sumera (2013, h. 43) menjelaskan bahwa yang termasuk dalam tindak kekerasan seksual bukan hanya perkosaan saja namun pada segala perlakuan negatif seperti menindas, memaksa, menekan dan segala hal yang berkonotasi seksual sehingga menimbulkan kerugian bagi korban. Lebih lanjut Sumera (2013, h.46) menjelaskan bahwa kekerasan seksual adalah setiap serangan yang bersifat seksual terhadap perempuan baik terjadi persetubuhan atau tidak, tanpa memedulikan hubungan antara pelaku dan korban. Tindakan kekerasan seksual sangat banyak contohnya, antara lain berupa percobaan perkosaan, perkosaan, perilaku sadisme dalam hubungan seksual, pemaksaan aktivitas seksual, merendahkan, menyakiti atau melukai korban. Tindakan kekerasan seksual beresiko menimbulkan dampak traumatis bagi kobannya, baik pada korban yang merupakan anak maupun korban yang merupakan orang dewasa.

Sulistyaningsih (2002, h. 9) menjelaskan bahwa bentuk kekerasan terhadap perempuan bukan hanya secara fisik namun juga berupa kekerasan psikologis, kekerasan ekonomi dan kekerasan seksual. Seksualitas memiliki ruang lingkup yang luas yang mencakup aspek biologis, emosi, perilaku, sikap, kepercayaan, nilai-nilai dan norma serta orientasi. Secara emosional korban kekerasan seksual mengalami stress, depresi, goncangan jiwa, adanya perasaan bersalah dan menyalahkan diri sendiri, rasa takut berhubungan dengan orang lain, bayangan kejadian kekerasan seksual, mimpi buruk, insomnia, ketakutan dengan hal yang berhubungan dengan penyalahgunaan termasuk benda, bau, tempat, kunjungan dokter, masalah harga diri, disfungsi seksual, sakit kronis, kecanduan, keinginan bunuh diri, keluhan somatik, dan kehamilan yang tidak diinginkan (Dalam Ciccarelli (2006). Sulistyaningsih (2002, h.9) menuliskan beberapa dampak psikologis wanita korban perkosaan antara lain adalah 96\% mengalami kecemasan, 96\% rasa lelah secara psikologis, 88\% kegelisahan tak henti, $88 \%$ rasa terancam dan $80 \%$ merasa diteror oleh keadaan. 
Gangguan kecemasan sendiri merupakan keadaan emosional yang mempunyai ciri keterangsangan fisiologis, perasaa tegang yang tidak menyenangkan, dan perasaan aprehensif bahwa sesuatu yang buruk akan terjadi (Nevis, Rathus, Greene : 2002, hal. 163). Gangguan kecemasan merupakan sebuah tipe gangguan mental yang ciri-ciri utamanya adalah kecemasan. Arumwardhani (2011, h. 259) mendefinisikan kecemasan sebagai emosi yang ditandai oleh perasaan bahaya, ketegangan, distress yang diantisipasikan dan/oleh timbulnya sistem syaraf yang simpatetik. Maslim (2001, hal. 74) menjelaskan ciri-ciri fisik dari kecemasan antara terjadi ketegangan motorik (gelisah, sakit kepala, gemetaran, tidak dapat santai) dan overaktivitas otonomik (kepala terasa ringan, berkeringat, jantung berdebar-debar, sesak nafas, keluhan lambung, pusing, mulut kering) sedangkan ciri-ciri kognitif dari kecemasan antara lain merasa cemas (khawatir akan terjadi nasib buruk, merasa seperti di ujung tanduk, sulit konsentrasi, dsb).

Acceptance and Commitment Therapy (ACT) dirancang oleh psikolog Steven Hayes. ACT merupakan suatu terapi yang menerapkan penerimaan untuk mengatasi semua masalah dan mengarahkan untuk individu memiliki komitmen utuk melakukan tindakan yang bernilai dalam mengatasi setiap masalah yang dihadapi (Sulistiowati, 2014, hal. 51). Terapi ACT adalah terapi yang menngunakan prinsip kesadaran, artinya klien melaksanakan terapi dengan sadar dan menjalani setiap prosesnya dengan kesadaran. Dalam ACT klien secara sadar diminta untuk merencanakan tindakantindakan efektif yang harus dikerjakan sehingga waktu, energi dan sumber daya yang dimiliki tidak dibuang sia-sia untuk mengontrol emosi negatif dan mengerjakan hal yang sia-sia melainkan bisa disalurkan mencapai hidup yang lebih bermakna. ACT disusun berdasarkan enam prinsip utama yang untuk mencapai dua tujuan utama (Harris, 2011, hal. 46). Dua proses yang terjadi di ACT adalah proses penerimaan dan proses komitmen. ACT membantu meningkatkan fleksibilitas psikologis dari yang tidak fleksibel menjadi lebih fleksibel. Kondisi psikologis yang tidak fleksibel akan membuat semakin sulit dalam menyesuaikan diri dengan keadaan yang dialaminya, namun semakin fleksibel seseorang maka semakin mudah dalam menerima dan bergerak mencapai tujuan yang ingin dicapainya.

Banyak hal yang bisa terjadi dalam kehidupan baik yang sesuai dengan rencana maupun yang di luar dugaan. Seringkali terjadi hal yang tidak sesuai dengan harapan, dan dianggap sebagai pengalaman yang tidak baik. Pengalaman yang baik menimbulkan perasaan positif dan pengalaman yang tidak baik menimbulkan perasaan 
negatif. Mengalami kekerasan seksual merupakan pengalaman negatif yang pastinya akan menimbulkan perasaan negatif. Kekerasan seksual membawa dampak emosional dan fisik kepada korbannya. Gejala klinis yang dapat muncul sebagai dampak dari pengalaman negatif berupa kekerasan seksual dapat bermacam-macam bentuknya. Salah satu gejala klinis yang mungkin dialami oleh korban kekerasan seksual adalah kecemasan. Gangguan-gangguan psikologis yang dialami seperti kecemasan, membuat individu tidak dapat memiliki hidup yang berkualitas, kaya dan bermakna. ACT mampu membantu individu dengan rentang masalah yang bervariasi seperti depresi, gangguan cemas, gangguan zat adiktif dan PTSD (Tania, 2018, h. 123). ACT merupakan suatu terapi yang dianggap lebih fleksibel dan efisien dalam menangani kasus kecemasan (Ismoyowati, 2018, h. 45).

Kejadian yang sudah terjadi tidak dapat dihapus dari kehidupan, atau dilupakan. Setiap kejadian kekerasan yang pernah dialami oleh korban akan terus diingat seumur hidup. Kekerasan seksual yang dialami menimbulkan dampak yang merugikan bagi korban, oleh sebab itu ACT dinilai sesuai karena akan mampu membantu korban umtuk menurunkan dampak kekerasan seksual yang dialami. Dengan ACT kecemasan diharapkan akan menurun dan korban kekerasan seksual akan memiliki hidup yang tetap baik walaupun pernah mengalami kejadian yang tidak baik.

\section{Metode}

Metode yang digunakan dalam penelitian ini adalah metode kuasi eksperimen dengan kasus tunggal, atau Quasi Experiment dengan Single-Case Design. Rancangan terapi yang digunakan adalah A-B-A design, dengan tujuan untuk melihat perubahan antara perilaku sebelum diberi terapi dan perilaku setelah diberi terapi, dimana A adalah baseline I, B adalah sesi intervensi dan A berikutnya adalah basline II. Pada tahap baseline I subjek dinilai tingkat kecemasan dan tingkat penerimaan dirinya dengan menggunakan skala kecemasan yaitu Hamilton Rating Scale for Anxiety dan skala penerimaan Acceptance and Action Questionnaire II tanpa subjek mendapatkan intervensi apapun dengan tujuan kita mendapatkan gambaran yang sebenarnya mengenai kondisi subjek. Tahap intervensi dilakukan sebanyak 4 kali dengan metode yang digunakan berupa pemberian terapi psikologis dengan menggunakan Acceptance and Commitment Therapy (ACT) untuk meningkatkan fleksibilitas psikologis. Setelah sesi intervensi maka kondisi subjek kembali diukur dengan menggunakan skala kecemasan yaitu Hamilton Rating Scale for Anxiety dan skala penerimaan Acceptance 
and Action Questionnaire II lagi untuk melihat kondisi subjek setelah mendapatkan intervensi berupa ACT.

Subjek penelitian didapatkan dari klien yang datang mencari bantuan ke PPT Seruni Kota Semarang. Klien yang digunakan sebagai subjek adalah wanita yang merupakan klien di PPT Seruni dan datang dengan keluhan mengalami masalah kekerasan dengan spesifikasi pernah mengalami kekerasan seksual, memenuhi kriteria mengalami gangguan kecemasan (ditunjukkan dari hasil tes dengan HARS dan AAQ II) serta belum pernah mendapatkan intervensi ataupun terapi psikologis sebelumnya. Dari hasil screening maka didapatkan dua orang klien yang sesuai dengan ketentuan tersebut dia atas.

Tabel 1.

Profil Subjek

\begin{tabular}{cccc}
\hline No & Keterangan & Subjek 1 & Subjek 2 \\
\hline 1 & Inisial & NK & CY \\
\hline 2 & Usia & 57 & 33 \\
\hline 3 & Alamat & Semarang & Demak \\
\hline 4 & Status & Bercerai & Menikah \\
\hline
\end{tabular}

Metode pengumpulan data yang digunakan sebagai dalam penelitian ini adalah :

\section{Wawancara}

Wawancara digunakan sebagai salah satu metode untuk mengumpulkan informasi sebanyak-banyaknya mengenai kondisi subjek. Wawancara yang digunakan adalah wawancara yang bersifat direktif yaitu wawancara dimana topik yang dibicarakan mengarahkan pada informasi yang diperlukan sesuai dengan tujuan penelitian ini.

\section{Observasi}

Observasi dalam penelitian ini dilakukan secara natural dan spontan tanpa menggunakan pedoman observasi dan dilakukan setiap sesi. Observasi bertujuan untuk melihat kondisi subjek secara umum,gejala-gejala yang mungkin terlihat, melihat perkembangan ataupun kemunduran yang mungkin terjadi selama proses terapi.

\section{Skala}

Skala yang digunakan untuk mengukur gejala klinis adalah skala kecemasan (Hamilton Rating Scale for Anxiety). Skala yang digunakan untuk mengukur fleksibilitas psikologis adalah skala penerimaan (Acceptance and Action Questionnaire II). AAQ II adalah alat tes yang dapat menunjukkan apakah ACT 
mampu memberikan perubahan pada subjek. AAQ II mengukur kecenderungan untuk mengontrol pikiran dan perasaan, serta kemampuan bersikap terhadap pikiran dan perasaan negatif (Ciarrochi, 2014). AAQ II terdiri dari 7 item pernyataan yang menggunakan 7 point-scale, dengan indikasi semakin rendah skor AAQ II maka subjek memiliki tingkat fleksibilitas psikologis yang lebih baik. Berdasarkan penelitian Hinton (2010) rentang reliabilitas AAQ II berada pada 0,76 0,87 sehingga dapat dinilai bahwa AAQ II konsisten dan akurat dalam mengukiur flleksibilitas psikologis.

Adapun teknis pelaksanaan pmberian intervensi adalah sebagai berikut :

Tabel 2.

Proses Pelaksanaan Terapi

\begin{tabular}{|c|c|c|c|c|}
\hline Sesi & $\begin{array}{l}\text { Pelaksana } \\
\text { an }\end{array}$ & $\begin{array}{l}\text { Proses } \\
\text { ACT }\end{array}$ & $\begin{array}{l}\text { Teknik yang } \\
\text { Digunakan }\end{array}$ & Tujuan \\
\hline \multirow{3}{*}{ Sesi 1} & Baseline I & - & $\begin{array}{l}\text { Pemberian } \\
\text { HARS dan } \\
\text { AAQ II, } \\
\text { Wawancara }\end{array}$ & $\begin{array}{l}\text { Mengetahui tingkat kecemasan dan } \\
\text { fleksibilitas psikologi, mendapatkan } \\
\text { informasi mengenai kondisi subjek }\end{array}$ \\
\hline & $\begin{array}{l}\text { Intervensi } \\
\text { (Sesi } 2 \\
\text { durasi } 90 \\
\text { menit) }\end{array}$ & \multirow{3}{*}{$\begin{array}{l}\text { Acceptan } \\
\text { ce \& } \\
\text { Mindfuln } \\
\text { ess } \\
\text { processe } \\
\text { s/ } \\
\text { Proses } \\
\text { Penerim } \\
\text { aan dan } \\
\text { Kesadar } \\
\text { an }\end{array}$} & Defusion & $\begin{array}{l}\text { Mengurangi penolakan terhadap pikiran } \\
\text { tentang pengalaman negatif, dan segala } \\
\text { pikiran negatif yang muncul }\end{array}$ \\
\hline & Intervensi & & $\begin{array}{l}\text { Acceptances } \\
\& \\
\text { Willingness }\end{array}$ & $\begin{array}{l}\text { Memberi ruang untuk semua pikiran dan } \\
\text { emosi negatif tanpa memengaruhi } \\
\text { perasaan (belajar membuat pikiran dan } \\
\text { emosi negatif jadi tidak bermakna) }\end{array}$ \\
\hline \multirow[b]{2}{*}{ Sesi 2} & Intervensi & & $\begin{array}{l}\text { Sense of self } \\
\text { as observer }\end{array}$ & $\begin{array}{l}\text { Menyadari setiap pikiran dan emosi } \\
\text { negatif yang muncul, kemudian belajar } \\
\text { untuk memilah mana yang patut diberi } \\
\text { perhatian dan yang tidak }\end{array}$ \\
\hline & Intervensi & \multirow{3}{*}{$\begin{array}{l}\text { Commit } \\
\text { ment \& } \\
\text { Behavior } \\
\text { processe } \\
\text { s/ } \\
\text { Proses } \\
\text { Komitme } \\
\text { n dan } \\
\text { Perubah } \\
\text { an } \\
\text { Perilaku }\end{array}$} & $\begin{array}{l}\text { Present } \\
\text { moment } \\
\text { awarenes }\end{array}$ & $\begin{array}{l}\text { Secara sadar dan fokus terhubung dan } \\
\text { terlibat secara penuh dengan kondisi saat } \\
\text { ini dan di sini }\end{array}$ \\
\hline \multirow[b]{2}{*}{ Sesi 3} & Intervensi & & $\begin{array}{l}\text { Clarity \& } \\
\text { contact with } \\
\text { value }\end{array}$ & $\begin{array}{l}\text { Menemukan tujuan hidup, memiliki } \\
\text { pegangan menuju pencapaian tujuan } \\
\text { hidup }\end{array}$ \\
\hline & Intervensi & & $\begin{array}{l}\text { Committed } \\
\text { actions }\end{array}$ & $\begin{array}{l}\text { Memiliki komitmen untuk melakukan } \\
\text { tindakan efektif untuk mencapai nilai dan } \\
\text { tujuan hidup }\end{array}$ \\
\hline
\end{tabular}


Philanthropy Journal of Psychology

Vol 4 Nomor 1 (2020), 69-81

ISSN 2580-6076 (Print), ISSN 2580-8532 (Online)

\begin{tabular}{|c|c|c|c|c|}
\hline Sesi 4 & Baseline II & - & $\begin{array}{l}\text { Pemberian } \\
\text { HARS dan } \\
\text { AAQ II, } \\
\text { Wawancara }\end{array}$ & $\begin{array}{l}\text { Mengetahui tingkat kecemasan dan } \\
\text { fleksibilitas psikologi, setelah } \\
\text { mendapatkan terapi ACT }\end{array}$ \\
\hline
\end{tabular}

Adapun hasil yang diperoleh adalah :

Tabel 2.

Hasil Terapi

\begin{tabular}{|c|c|c|c|}
\hline Subjek & Ketera & Skala & Hasil \\
\hline \multirow{4}{*}{ Subjek 1} & Baseline I & HARS & $\begin{array}{l}30 \text { (kecemasan } \\
\text { berat) }\end{array}$ \\
\hline & & AAQ II & $\begin{array}{l}43 \\
\text { (penerimaan } \\
\text { sangat rendah) }\end{array}$ \\
\hline & Baseline II & HARS & $\begin{array}{l}13 \text { (kecemasan } \\
\text { rendah) }\end{array}$ \\
\hline & & AAQ II & $\begin{array}{l}17 \\
\text { (penerimaan } \\
\text { baik) }\end{array}$ \\
\hline \multirow{4}{*}{ Subjek 2} & Baseline I & HARS & $\begin{array}{l}34 \text { (kecemasan } \\
\text { berat) }\end{array}$ \\
\hline & & AAQ II & $\begin{array}{l}46 \\
\text { (penerimaan } \\
\text { sangat rendah) }\end{array}$ \\
\hline & Baseline II & HARS & $\begin{array}{l}5 \text { (tidak } \\
\text { mengalami } \\
\text { kecemasan) }\end{array}$ \\
\hline & & AAQ II & $\begin{array}{l}19 \\
\text { (penerimaan } \\
\text { baik) }\end{array}$ \\
\hline
\end{tabular}

\section{Diskusi}

Menurut Komnas Perempuan, kekerasan seksual adalah setiap hal baik berupa ucapan maupun perbuatan yang dilakukan untuk menguasai atau memanipulasi orang lain serta membuatnya terlibat dalam aktifitas seksual yang tidak dikehendaki. Aspek penting dalam kekerasan seksual : 1) aspek pemaksaan dan aspek tidak adanya persetujuan dari korban, 2) korban tidak/belum mampu memberikan persetujuan. Menurut Kamus Besar Bahasa Indonesia (https://www.kamusbesar.com/kekerasanseksual) kekerasan seksual adalah setiap perbuatan yang berupa pemaksaan hubungan seksual , pemaksaan hubungan seksual dengan cara tidak wajar, dan/atau tidak sesuai, pemaksaan hubungan seksual dengan orang lain untyk komersial dan/atau dengan tujuan tertentu (UU No. 23 Tahun 2004 tentang Penghapusan Kekerasan Dalam Rumah 
Tangga). Tindakan kekerasan seksual tidak hanya berupa tindakan hubungan seksual secara paksa, namun termasuk juga aktivitas lain seperti melihat, meraba, penetrasi (tekanan), pencabulan dan pemerkosaan. Suhandjati (2004) mengatakan bahwa seseorang dikatakan sebagai korban kekerasan apabila menderita kerugian fisik, mengalami luka atau kekerasan psikologis, trauma emosional, tidak hanya dipandang dari aspek legal, tetapi juga sosial dan kultural. Dampak yang muncul dari kekerasan seksual kemungkinan adalah depresi, fobia, dan mimpi buruk, curiga terhadap orang lain dalam waktu yang cukup lama. Dampak yang jelas terlihat adalah kecemasan.

15 bentuk kekerasan seksual www.komnasperempuan.or.id dari hasil pemantauannya selama 15 tahun (1998-2013) yaitu: perkosaan, intimidasi seksual termasuk ancaman atau percobaan perkosaan, pelecehan seksual, eksploitasi seksual, perdagangan perempuan untuk tujuan seksual, prostitusi paksa, perbudakan seksual, pemaksaan perkawinan, cerai gantung, pemaksaan kehamilan, pemaksaan aborsi, pemaksaan penggunaan kontrasepsi dan sterilisasi, penyiksaan seksual, penghukuman tidak manusiawi dan bernuansa seksual, praktik tradisi bernuansa seksual yang membahayakan atau mendiskriminasi perempuan, kontrol seksual termasuk lewat aturan diskriminatif beralasan moralitas dan agama.

Kedua subjek dalam penelitian ini mengalami beberapa peristiwa yang termasuk dalam kategori kekerasan seksual. Pelaku kekerasan seksual adalah suami subjek. Berdasarkan penelitain yang dilakukan, maka diketahui latar belakang subjek yaitu subjek 1 (NK) datang ke PPT. Seruni karena menjadi korban kekerasan dalam rumah tangga. NK tinggal di Semarang, sudah bercerai, tinggal di rumah seorang diri, bekerja wiraswasta. Mengalami kekerasan secara fisik (dipukul, ditendang, dicekik), kekerasan secara verbal (dimaki-maki, diancam), kekerasan secara seksual (dipaksa melayani saat tidak mau, cerai gantung). Subjek 2 (CY) datang ke Seruni karena menjadi korban kekerasan dalam rumah tangga. Ybs tinggal di Demak, tidak bercerai, bekerja wiraswasta, tinggal bersama 2 orang anak, suami di Surabaya, suami selingkuh, mengalami kekerasan secara fisik (diseret di depan umum, ditendang, ditampar), kekerasan secara verbal (perkataan yang menyakitkan/makian), kekerasan secara seksual (tidak disupport saat kehamilan bermasalah bahkan disarankan aborsi, dipaksa berhubungan seks. Kekerasan seksual yang dialami tidak hanya berlangsung sekali namun berkali-kali dan dalam kurun waktu yang cukup lama. Kejadian tersebut menimbulkan kecemasan yang sampai saat ini masih dirasakan oleh subjek. 
Kecemasan adalah suatu keadaan aprehensi atau keadaan khawatir yang meyakini bahwa sesuatu yang buruk akan segera terjadi. Kalat (2010, h. 128-130) menuliskan banyak reaksi yang merupakan indikator dari kecemasan. Ciri fisik kecemasan antara lain : sering buang air kecil, merasa sensitif atau mudah marah, jarijari atau anggota tubuh menjadi dngin, telapak tangan berkeringat, terjadi kekencangan pada pori-pori kulit perut atau dada. Ciri-ciri kognitif kecemasan antara lain pikiran terasa bercampur aduk atau kebingungan, khawatir tentang sesuatu, ketakutan akan kehilangan kontrol, berpikir bahwa dunia mengalami keruntuhan, sangat waspada terhadap sensasi ketubuhan. Ciri-ciri behavioral kecemasan antara lain perilaku menghindar, perilaku melekat dan dependen, perilaku terguncang.

Beberapa ciri kecemasan dialami subjek sejak kejadian sampai dengan saat dilaksanakan penelitan dan subjek mendapatkan terapi ACT. Pada awal sesi terapi kecemasan masih tinggi kemudian mulai menurun perlahan dan terus mengalami penurunan hingga saat teapi selesai. Kecemasan diungkap dengan menggunakan skala kecemasan HARS dan didapatkan hasil bahwa kedua subjek masuk dalam kategori mengalami kecemasan berat yang ditunjukkan dengan skor HARS subjek NK di angka 30 (kecemasan berat) dan subjek CY di angka 34 (kecemasan berat). Kecemasan yang dialami subjek mengalami penurunan ketika subjek telah memiliki penerimaan yang baik akan peristiwa apapun yang terjadi di hidupnya. Kondisi penerimaan subjek di awal penelitan tergolong dalam kategori sangat rendah yaitu hasil skala AAQ II subjek 1 (NK) mendapat skor 43 (penerimaan sangat rendah) dan subjek 2 (CY) mendapat skor 46 (penerimaan sangat rendah). Hal tersebut memberi gambaran bahwa di awal penelitian kedua subjek korban kekerasan seksual tersebut mengalami kecemasan berat dan memiliki penerimaan diri yang sangat rendah kemudian setelah diberikan ACT didaptkan hasil bahwa kecemasan mulai turun diiringin dengan meningkatnya level penerimaan. Setelah pemberian ACT didapatkan peningkatan penerimaan diri dan penuunan kecemasan. Subjek 1 (NK) menunjukkan penurunan yang dapat dilihat dari skor HARS sebesar 13 dan AAQ II sebesar 17, sedangkan subjek 2 (CY) menunjukkan penurunan yang dapat dilihat dari hasil skor HARS sebesar 5 dan AAQ II sebesar 19.

Penerimaan bisa dimiliki apabila subjek sudah memiliki fleksibilitas psikologis yang cukup baik yang membuatnya bisa menerima segala hal yang terjadi baik itu hal baik maupun hal yang tidak baik. Akhir sesi ACT membantu subjek menemukan nilai dan tujuan hidup yang harus terus dipegang dan diusahakan oleh subjek. Subjek harus 
memiliki komitmen untuk melakukan segala tindakan yang mengarah kepada pencapaian nilai dan tujuan hidup. Subjek harus tetap konsisten apapun kondisi yang terjadi dan harus sadar jika selalu ada kemungkinan gagal. Subjek berproses untuk menerima keseluruhan hidupnya dan fokus pada hal yang bermakna saja. Subjek disadarkan bahwa kejadian masa lalu sudah berlalu dan tidak dapat diulang sehingga percuma jika terus fokus pada peristiwa masa lalu. Di akhir sesi subjek 1 (NK) telah dapat memutuskan bahwa ia akan menerima seluruh keluarganya yang dianggap sudah menyakitinya, menerima anaknya kembali dan mulai bekerjasama dalam mencari nafkah agar kondisi ekonomi keluarga lebih stabil. Subjek yang awalnya masih mempermasalahkan perihal harta gono-gini memutuskan untuk menyerahkan semua keputusan pada kebijakan pengadilan karena jika terus melakukan usaha penuntutan akan membuang waktu, energi dan juga biaya yang besar. Subjek 2 (CY) telah memutuskan untuk membuka usaha sendiri agar tidak lagi tergantung pada suaminya, subjek sudah berserah dan tidak lagi memaksakan kehendak minta bercerai karena subjek akan menjalani semua proses dalam rumahtangganya dengan ikhlas. Ketika subjek telah mampu melepaskan diri dari luka yang dialami di masa lalu maka kecemasan akan turun dengan sendirinya karena seluruh sumber daya yang dimiliki subjek diarahkan untuk mencapai tujuan hidup yang lebih bermakna. Kedua subjek yang awalnya ada dalam kondisi tidak bisa menerima kehiduoannya, kemudian menghabiskan waktu dan seluruh sumber daya yang dimiliki untuk membuat kondisi hidupnya seperti idealismenya kini sudah memiliki pandangan yang berbeda. Subjek lebih bisa menerima segala sesuatu dengan ikhlas sehingga sudah tidak lagi merasakan semua gejala kecemasan yang dulu dirasakan serta sudah memiliki rencana kehiduoan yang mantap untuk masa depan. Apabila setiap rencana hidup tersebut dilakukan dengan konsisten dan tercapai maka subjek akan memiliki kepuasan terhadap keseluruhan ranah hidupnya.

\section{Kesimpulan}

Secara keseluruhan, tujuan penelitia ini dapat dikatakan tercapai. Keberhasilan dilihat dari tercapainya tercapainya tujuan terapi yang memberikan dampak positif yaitu penurunan kecemasan Keberhasilan penelitian dapat dilihat dari hasil pre-test dan post-test yang menunjukkan adanya penurunan angka kecemasan yang cukup signifikan. 
Berdasarkan hasil penelitian yang dilakukan dapat disimpulkan bahwa bahwa pada tiap-tiap subjek penelitian terdapat perbedaan hasil skala AAQ II (skala penerimaan diri) dan skala HARS (skala kecemasan). Pada subjek 1 (NK) hasil pre-test menunjukkan angka HARS sebesar 30 dan AAQ II sebesar 43, kemudian setelah diberikan terapi ACT kemudian diukur lagi dan didapatkan hasil HARS sebesar 13 dan AAQ II sebesar 17. Pada subjek 2 (CY) hasil pre-test menunjukkan angka HARS sebesar 34 dan AAQ II sebesar 46, kemudian pada post-test atau setelah diberikan Act didapatkan hasil HARS sebesar 5 dan AAQ II sebesar 19.

Dari perbedaan hasil pada pre-test dan post-test yang didapat maka dapat dilihat bahwa pemberian ACT memberikan dampak berupa peningkatan penerimaan dan penurunan kecemasan.

Penelitian ini menemukan bahwa korban kekerasan seksual mengalami kecemasan yang tinggi, selain itu dalam proses pelaksanaan yang melibatkan banyak sesi konseling didapati bahwa korban kekerasan menyimpan perasaan marah. Kemarahan tersebut tidak bisa diluapkan sehingga menimbulkan perasaan tidak terima dengan kondisinya. Perasaan tidak terima tersebut yang kemudian menimbulkan kecemasan yang tinggi. Bagi peneliti selanjutnya yang berminat untuk meneliti korban kekerasan seksual, maka variabel kemarahan bisa dijadikan objek untuk diteliti.

\section{Daftar Pustaka}

Arumwardhani, A. 2011. Psikologi Kesehatan. Yogyakarta : Galangpress.

Azwar, S. 2004. Metode Penelitian. Yogyakarta : Pustaka Pelajar.

Carr, A. 2004. Positive Psychology - The Science of Happiness and Human Strengths. New York : Brunner - Routledge.

Ciarrochi, J., Bilich, L. 2006. Acceptance and Commitment Therapy. Measurement Package. Process Measures of Potential Relevance to ACT. School of Psychology, University of Wollongong.

Eaker, Bunnie. 1986. Unlocking the Family Secret in Family Play Therapy. Jurnal Child and Adolescent Social Work. Vol. 3. No. 4

Elita, Y., Sholihah, A., Sahiel, S. Acceptance and Commitment Therapy (AACT) Bagi Penderita Gangguan Stress Pasca Bencana. Jurnal Konseling Pendidikan. Vol.5. No.2. Th.2017. Hal. 97-101 
Harris, R. 2011. The Happiness Trap = Hati-Hati Dengan Kebahagiaan Anda. Yogyakarta : Kanisius.

Hayes, S. C. , Fletcher, L. 2005. Relational Frame Theory, Acceptance and Commitment Therapy and A FunctionalAnalitic Definition of Mindfullness. Journal of Rational Emotive \& Cognitive Behavior Therapy. Vol. 23. No. 4. Winter 2005 : 315-336.

Hayes, S. C. 2005. Instructor's Manual for Acceptance and Commitment Therapy. Mill Valley, California : Psychotherapy.net

Hinton, M., Gaynor, S. T. 2010. Cognitive Defudion Of Psychological Distress, Dysphoria, and Low Self Esteem ; Randomized Technique Evaluation Trial of Vocalizing Strategies. International Journal Behavioral Consultation and Therapy. Vol. 6. No. 3. Hal 164.

https://www.cnnindonesia.com/gaya-hidup/20181126110630-284-349231/

https://www.brilio.net/stories/kekerasan/

Ismoyowati, T.W. 2018. Pengaruh Acceptance and Commitment Therapy (ACT) Terhadap Perubahan Kecemasan Dan Self Efficacy Pada Pasien Dengan Hemodialisa Di RS. Sint Carolus Jakarta. Jurnal Kesehatan STIKES Bethesda. Vol. 5. No. 2. Januari. 2018. Hal. 44-48.

Jurnal Masalah-Masalah Hukum (MMH, p-ISSN : 2086-2695, e-ISSN : 25274716) published by Faculty of Law Diponegoro University

Kalat, J. W. 2010. Biopsikologi, Edisi 9. Jakarta : Salemba Humanika.

Komnas Perempuan. (2013). Kekerasan Seksual. Retrieved August 20, 2004, from http://www.komnasperempuan.go.id/wp-content/uploads/2013/12KekerasanSeksual-Kenali-dan-Tangani.pdf

Komnas Perempuan. 15 Bentuk kekerasan Seksual https://www.komnasperempuan.go.id/file/pdf file/Modul\%20dan\%20Pedoman/Kek erasan\%20Seksual/15\%20BTK\%20KEKERASAN\%20SEKSUAL.pdf diunduh tanggal 15 Maret 2019

Maslim, R. 2001. Diagnosis Gangguan Jiwa, Rujukan Ringkas PPDGJ-III. Jakarta : PT. Nuh Jaya.

Noviana, Ivo. 2015. Kekerasan Seksual Terhadap Anak : Dampak dan Penanganannya. Child Sexual Abuse : Impact and Hendling. Sosio Informa. Vol. 01, No. 1, JanuariApril 2015, hal 13-28.

Purwanti, A., Hardiyanti, M. Strategi Penyelesaian Tindak Kekerasan Seksual Terhadap Perempuan dan Anak Melalui RUU. Kekerasan Seksual. Jurnal Masalah Hukum. Vol. 47. No. 2. Tahun 2018. 
Putriana, A. Kecemasan Dan Strategi Coping Pada Wanita Korban Kekerasan Dalam Pacaran (Studi Kasus di Samarinda). Jurnal Psikoborneo. Vol.6. No. 3. 2018. Hal. 619-703.

Rusyidi, B., Bintari, A., Wibowo, H. Pengalaman dan Pengetahuan tentang Pelecehan Seksual : Studi Awal di Kalangan Mahasiswa Perguruan Tinggi. Social Work Jurnal. Vol. 9. No. 1. Hal. 75-85.

Sulistiowati, N.M.D., Keliat, B. A. Wardani, I. Y. 2014. Pengaruh Acceptance And Commitment Therapy Terhadap Gejala dan Kemampuan Klien dengan Resiko Perilaku Kekerasan. Jurnal Keperawatan Jiwa. Vol. 2. No. 1. Mei 2014. Hal 51-57.

Sumera, Marcheyla. 2013. Perbuatan Kekerasan/Pelecehan Seksual Terhadap Perempuan. Lex et Societatis, Vol. I/No.2/Apr-Jun/2013

Tania, M., Suryani, Hernawaty, T. Penggunaan Acceptance and Commitment Therapy (ACT) Terhadap Kecemasan Narapidana Waita : Systemiatic Review. Jurnal Keperawatan BSI. Vol. VI. No. 2. September. 2018 